\title{
Understanding the origin of high oxygen evolution reaction activity in the high $\mathrm{Sr}$-doped perovskite
}

\author{
Sanzhao Song a , Jing Zhou a,c, Jian Sun a,b, Shiyu Zhang a,b, Xiao Lin a,c, Zhiwei Hu d, Jun Hu a,b, \\ Linjuan Zhang a,b,c,*, Jian-Qiang Wang a,b,c \\ a Key Laboratory of Interfacial Physics and Technology, Shanghai Institute of Applied Physics, Chinese Academy of Sciences, Shanghai 201800, China \\ b University of Chinese Academy of Sciences, Beijing 100049, China \\ c Dalian National Laboratory for Clean Energy, Dalian 116023, Liaoning, China \\ d Max Planck Institute for Chemical Physics of Solids, Nöthnitzer Strasse 40, Dresden 01187, Germany
}

\section{A R T I C L E I N F O}

\section{Article history:}

Received 7 October 2019

Accepted 3 November 2019

Published 5 April 2020

Keywords:

Molten salt

Perovskite

Oxygen evolution reaction

Surface reconstruction

Oxygen hole

\begin{abstract}
A B S T R A C T
Effective electrocatalysis is crucial for enhancing the efficiency of water splitting to obtain clean fuels. Herein, we report a system of interesting and high-performance Sr-doped perovskite electrocatalysts with porous structures, obtained via a facile molten salt method and applied in the oxygen evolution reaction (OER). With increasing the Sr content, the valence states of Co and Fe ions do not clearly increase, according to the Co- $\mathrm{L}_{2,3}$ and $\mathrm{Fe}-\mathrm{L}_{2,3}$ as well as the Co-K and the Fe-K X-ray absorption spectroscopy, whereas doped holes are clearly observed in the $\mathrm{O}-\mathrm{K}$ edge. High-resolution transmission electron microscopy indicates the appearance of an amorphous layer after the electrochemical reaction. We conclude that the formation of the amorphous layer at the surface, induced by Sr doping, is crucial for achieving high OER activity, and we offer insights into the self-reconstruction of the OER catalyst.
\end{abstract}

(C) 2020, Dalian Institute of Chemical Physics, Chinese Academy of Sciences. Published by Elsevier B.V. All rights reserved.
Electrocatalytic oxygen evolution reaction (OER) has been extensively studied because it is of fundamental importance in renewable energy technologies, such as water splitting, $\mathrm{CO}_{2}$ reduction, rechargeable metal-air batteries, and regenerative fuel cells [1-3]. OER is known for its complexity and slow kinetics owing to four concerted proton-electron transfer steps as well as oxygen-oxygen bond formation [4,5]. Therefore, developing efficient OER catalysts and understanding the mechanism involved are imperative and are the main focus of the research [2,6].

Recently, numerous experimental results have pointed out that OER catalysts can undergo a drastic self-reconstruction during OER treatment [7-11]. For instance, Fabbri et al. [12] reported that dynamic surface self-reconstruction was the main driving force for highly OER-active perovskite-based catalysts. In our previous work, we found that the surface of the catalyst was transformed into a definite coordination-unsaturated structure under electrochemical conditions, which is responsible for the outstanding performance of the material [13]. Unfortunately, the complexity of the multi-component structure impedes the precise structure identification, thus greatly limiting the understanding of the OER pro-

\footnotetext{
* Corresponding author. Tel: +86-21-39194148; Fax: +86-21-39194028; E-mail: zhanglinjuan@sinap.ac.cn

This work was supported by the "Transformational Technologies for clean Energy and Demonstration", Strategic Priority Research Program of the Chinese Academy of Sciences (XDA2100000), the Youth Innovation Promotion Association, Chinese Academy of Sciences (2014237), the National Natural Science Foundation of China (21876183), and the Scientific Instrument Developing Project of the Chinese Academy of Sciences (YJKYYQ20180066).
} 
cess over these catalysts, despite employing the operando techniques [14-16]. Thus far, probing the reconstruction and identifying the true catalytically active components at an atomic resolution has remained highly challenging. Therefore, it is necessary to develop a series of catalysts with well-defined structures to explore the origin of the surface reconstruction and the relation between the surface structure and OER activity.

Perovskite oxides $\left(\mathrm{ABO}_{3}\right)$ have been regarded as promising electrocatalysts toward the OER [17-20]. In this work, we prepared perovskite $\mathrm{LaCo}_{0.8} \mathrm{Fe}_{0.2} \mathrm{O}_{3-\delta}$ with different $\mathrm{Sr}$ doping levels. The electrocatalytic performance indicated that $\mathrm{La}_{0.2} \mathrm{Sr}_{0.8} \mathrm{Co}_{0.8} \mathrm{Fe}_{0.2} \mathrm{O}_{3-\delta}$ (LSCF28) exhibited a low overpotential and small Tafel slope. Surface analysis indicated that the thickness of an amorphous layer of the material after reaction increases with increasing $\mathrm{Sr}$ content. The amorphous layer was considered as an activity center, which had also been found previously $[10,21,22]$. We found that as the Sr content increased, no noticeable change in the valence states of Co and Fe ions was observed, whereas doped holes at the $02 p$ state were clearly observed.

The $\mathrm{La}_{1-y} \mathrm{Sr}_{y} \mathrm{Co}_{0.8} \mathrm{Fe}_{0.2} \mathrm{O}_{3-\delta}(y=0,0.4,0.8)$ denoted as LCF, LSCF64, and LSCF28 were readily synthesized by a molten salt method (see Supporting Information for details). In the precipitation reaction, a salt mixture acted as a solvent during the reaction leading to a short reaction time and significantly small crystal sizes $[23,24]$. The structural information of the as-prepared powder is shown in Fig. 1(a). It was found that the perovskite-type structure was obtained, as shown the Fig. 1(b).
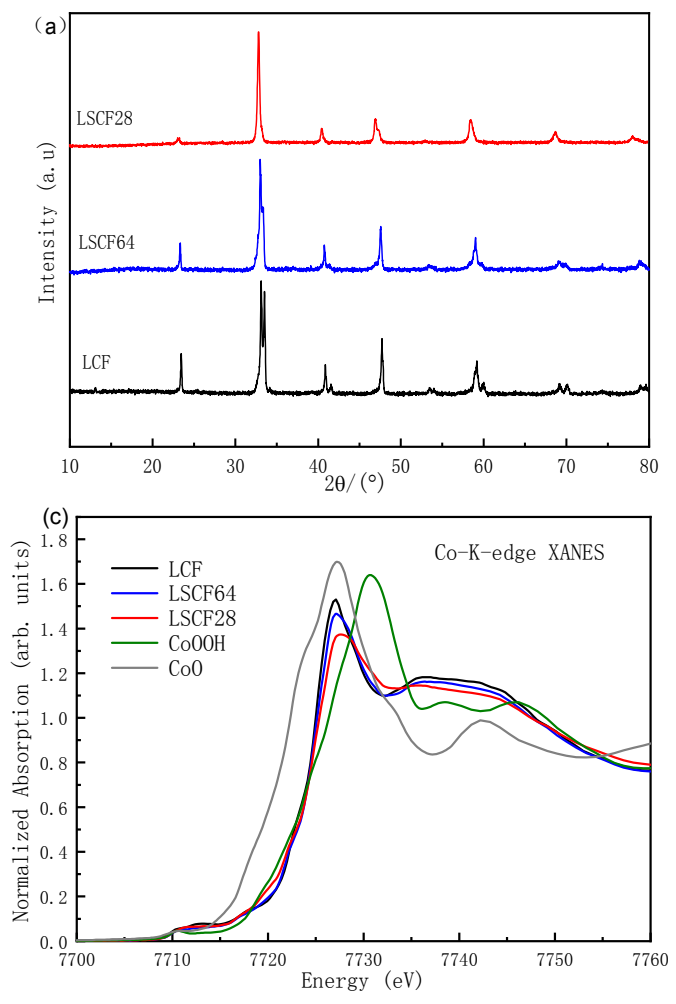

Fig. 1. (a) XRD patterns of the $\mathrm{La}_{1-y} \mathrm{Sr}_{y} \mathrm{Co}_{0.8} \mathrm{Fe}_{0.2} \mathrm{O}_{3-\delta}(y=0,0.4,0.8)$; (b) LSCF crystal structure (La and Sr are at the same positions, which are denoted by green, while $\mathrm{Co}(\mathrm{Fe})$ and $\mathrm{O}$ are denoted by blue and red, respectively; (c) Co K-edge XANES spectra of LCF, LSCF64, LSCF28, and various reference samples; (d) Fe K-edge XANES spectra of the samples.

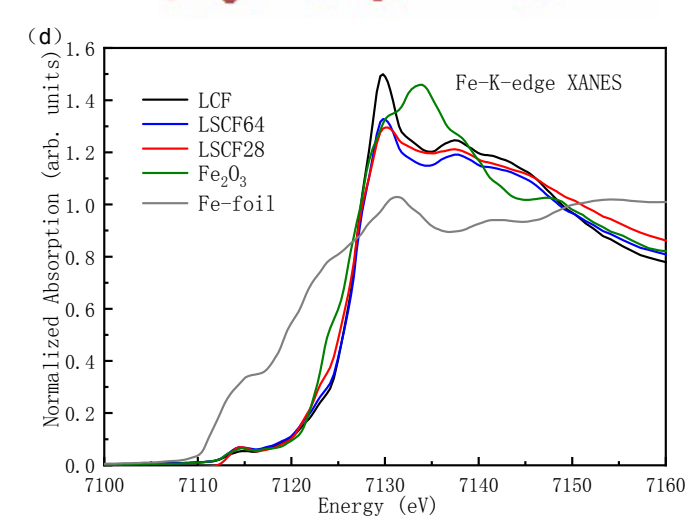

In addition, a notable shift of the diffraction line toward lower $2 \theta$ angles was observed with increasing the Sr content. This can be ascribed to the relatively large ionic radius of the $\operatorname{Sr}(\mathrm{II})$ ion (1.44 $\AA$ ) as compared with that of the La(III) ion (1.36 ̊̊) [25]. Scanning electron microscopy (SEM) was employed to determine the morphologies of the samples. In previous work, it has been found that the Fe content and the molten-salt approach are essential for producing a specific porous structure in LSCF perovskite oxides [26]. Here, we found that with increasing the Sr content, the porous structure and nanosize of the particles remained unchanged, as shown in Fig. S1. Furthermore, BET experiments indicated that all the particles had almost the same specific surface areas, as plotted in Fig. S2. Conclusively, the $\mathrm{Sr}$ content slightly affects the morphology of the sample.

To further study the electronic and geometric structures, we employed X-ray absorption spectroscopy (XAS) measurements. Generally, XAS is a powerful technique for investigating the oxidation states of transition metals with element-selective characters. The Co K-edge X-ray absorption near-edge structure (XANES) for LCF, LSCF64, and LSCF28 as well as for the reference samples are shown in Fig. 1(c). It could be clearly observed that the line shapes of the Co K-edge XANES spectra for the catalysts are very similar. We can conclude that the electronic structures and the local structures of the Co ions did not change upon Sr doping. Generally, the position of the adsorption edge reflects the oxidation state of the Co ion [27]. The absorption edges in LCF, LSCF64, and LSCF28 are located at the same energy as that of the $\mathrm{Co}^{3+}$ reference of $\mathrm{CoOOH}$, suggesting that the Co ions exist in the Co(III) oxidation state. The spectral

(b)

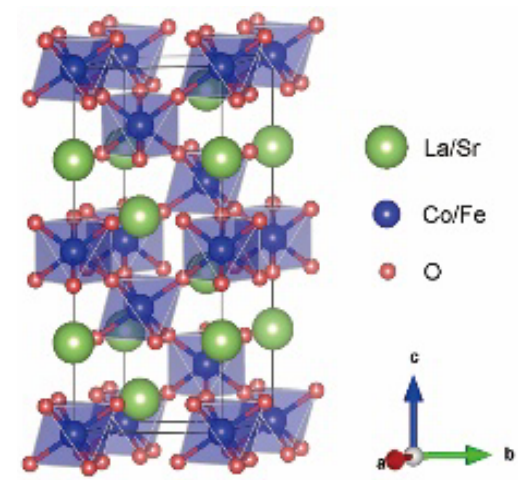



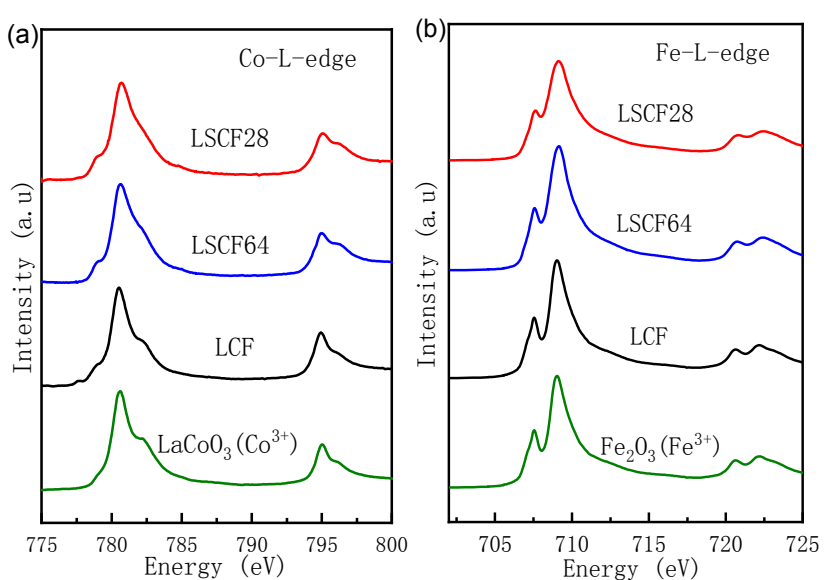

Fig. 2. (a) Co $\mathrm{L}_{2,3}$-edge XAS spectra of LCF, LSCF64, and LSCF28 as well as $\mathrm{LaCoO}_{3}(3+$ ); (b) Fe L2,3-edge XAS of LCF, LSCF64, and LSCF28 as well as $\mathrm{Fe}_{2} \mathrm{O}_{3}(3+)$.

evolution and absorption peaks can be discerned more clearly in the derivative curves of the XANES spectra, as confirmed in Fig. S3(a), which also revealed that the oxidation state was unchanged [28-31]. Moreover, the Fe K-edge XANES spectra in Fig. 1(d) and Fig. S3(b) revealed that the Fe ion has a similar trivalent state.

Considering that the XANES at the transition metal K-edge has a typical probing depth in micrometers, we performed soft XAS measurements at the transition metal $\mathrm{L}_{2,3}$-edge to study the valence states of $\mathrm{Co}$ and $\mathrm{Fe}$ ions at the sample surface using a total electron yield (TEY) mode, which has a typical exploring depth of 2-5 nm. The room-temperature Co L2,3-edge XAS
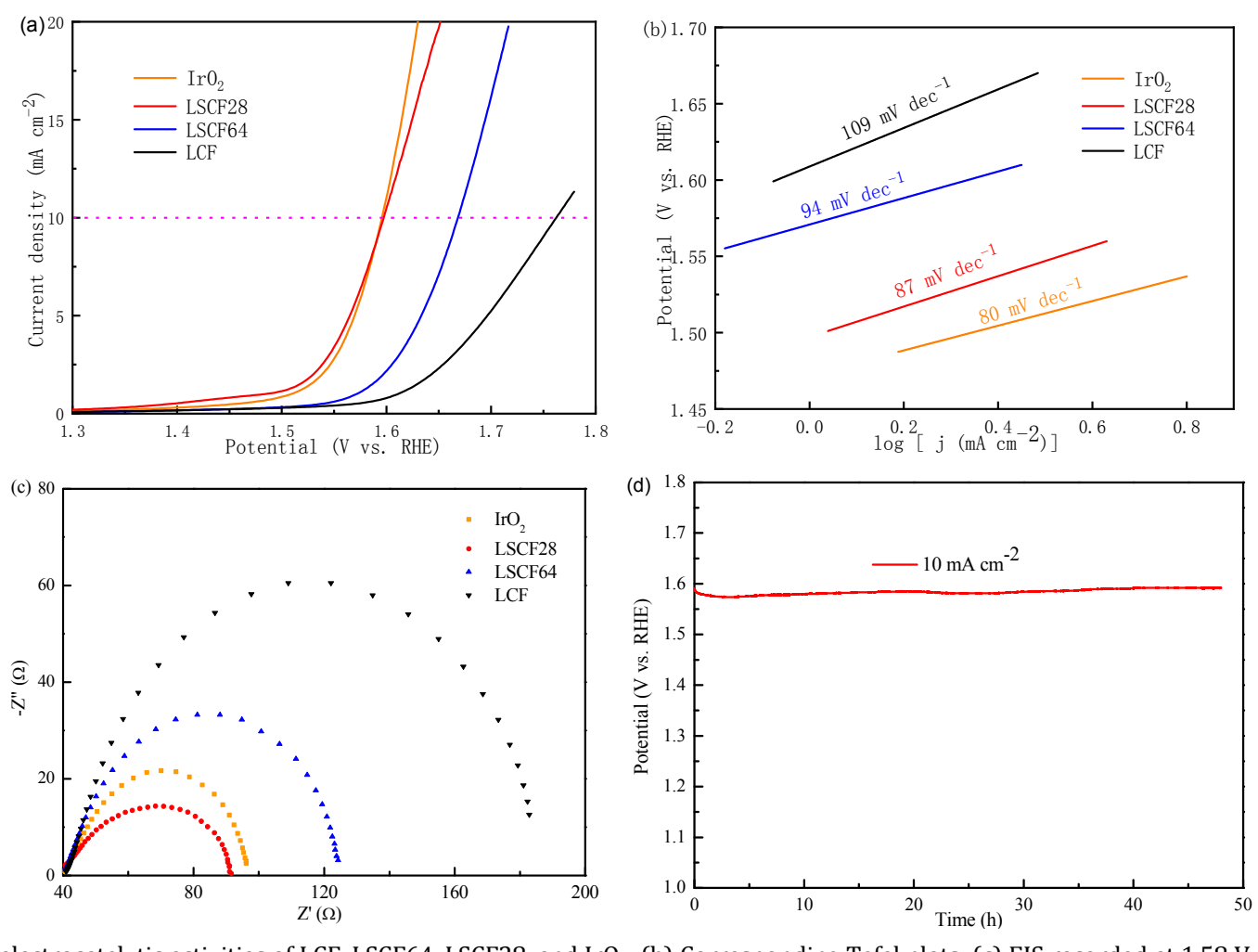

Fig. 3. (a) LSVs electrocatalytic activities of LCF, LSCF64, LSCF28, and $\mathrm{IrO}_{2}$; (b) Corresponding Tafel plots; (c) EIS recorded at $1.58 \mathrm{~V}$ (vs. RHE) under the influence of an $\mathrm{AC}$ voltage of $10 \mathrm{mV}$; (d) Chronopotentiometric measurement at $j=10 \mathrm{~mA} \mathrm{~cm}^{-2}$.

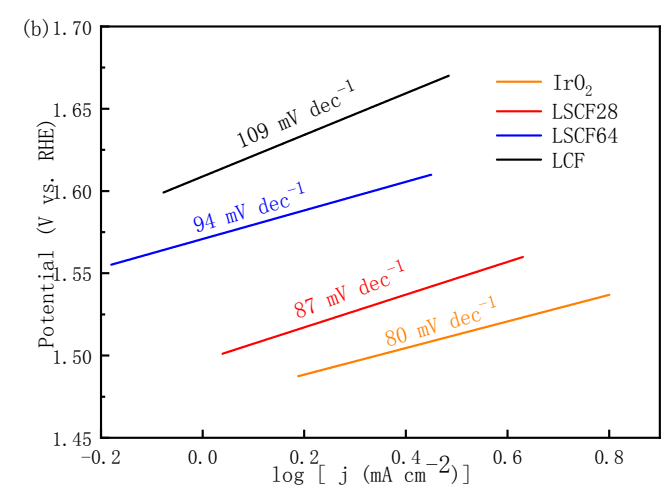

spectra of the LCF, LSCF64, and LSCF28 as well as $\mathrm{LaCoO}_{3}$, serving as a trivalent reference, are shown in Fig. 2(a). It was found that $\mathrm{LCF}$ has a $\mathrm{Co}^{3+}$ state, which remained unchanged with increasing $\mathrm{Sr}$ content. Similarly, the Fe $\mathrm{L}_{2,3}$-edge XAS spectra show that the Fe ion has a trivalent state, as illustrated in Fig. 2(b).

The soft X-ray absorption spectrum at the $\mathrm{O}-\mathrm{K}$ edge is known to be very sensitive to the doped hole at the $02 p$ state [32]. Fig. S4 shows the O-K XAS spectra of the samples studied. Noticeably, Sr doping leads to a new pre-edge peak at $528 \mathrm{eV}$, which represents the doped hole at the $02 p$ state $[33,34]$. However, the doped holes cannot totally compensate the $\mathrm{Sr}$ doping level, because, at $\mathrm{Sr}=0.8$, the spectral weight of the energy at $528 \mathrm{eV}$ is much lower than that of $\mathrm{Li}_{0.66} \mathrm{CoO}_{2}[34,35]$. Therefore we can conclude that the high $\mathrm{Sr}$ content would lead to oxygen vacancies.

The electrocatalytic activities of all the obtained samples and $\mathrm{IrO}_{2}$ reference for OER were evaluated by linear sweep voltammetry (LSV) measurements conducted in an $\mathrm{O}_{2}$-saturated $0.1 \mathrm{~mol} \mathrm{~L}^{-1} \mathrm{KOH}$ at a scan rate of $5 \mathrm{mV} \mathrm{s}^{-1}$ and a rotation speed of $1600 \mathrm{rpm}$, as plotted in Fig. 3(a). All potential values were IR-corrected during each LSV measurement to compensate for the resistance of the solution. The LSV curve measurements were performed on the fully activated sample that underwent cyclic voltammetry (CV) scans. It is important to study the overpotential at a current density of $10 \mathrm{~mA} \mathrm{~cm}-2$, which matches the sunlight flux (based on 10\% solar-to-fuel conversion efficiency) [36]. We found that LSCF28 had approximately the same overpotential, which achieved a current density of $10 \mathrm{~mA} \mathrm{~cm}^{-2}$ at a comparably small $\eta$ value of $0.35 \mathrm{~V}$, 
which is more negative than those of LSCF64 $(\eta=0.42 \mathrm{~V})$ and LCF ( $\eta=0.53 \mathrm{~V}$ ). Moreover, as displayed in Fig. 2(b), LSCF28 presents a smaller Tafel slope of $87 \mathrm{mV} \mathrm{dec}^{-1}$ compared to those of the others. These results clearly demonstrate the potential of LSCF28 as an oxygen evolution catalyst.

To gain more information on the kinetics of the OER, electrochemical impedance spectroscopy (EIS) measurements were performed to obtain the charge transfer resistances shown in Fig. 3(c). LSCF28 possessed a good charge transfer resistance $\left(R_{\mathrm{ct}}\right)$ with the value of $58 \Omega$, while those of the LSCF64 and LCF samples were 83 and $125 \Omega$, respectively. Long term testing is essential for determining the duration of application. As shown in Fig. 2(d), we also conducted chronopotentiometric measurements to evaluate the catalytic durability of LSCF28, and a nearly constant potential was observed for over $48 \mathrm{~h}$, as well as good electrochemical stability.

To further compare with the specific activity, we calculated by normalizing with the real oxide surface areas, using BET theory. The results are plotted in Fig. S5. Furthermore, according to the SEM analysis, the samples exhibited similar porous morphologies and specific surface areas. However, it could be observed that the OER activity increased with the $\mathrm{Sr}$ content. Therefore, we considered that the additional increase in the OER activity implies that there is an underlying effect factor.

Many studies have reported that the electronic and crystal structures of catalysts change after OER treatment [37]. Therefore, it was highly desirable to investigate the surface structures of the samples after electrochemical treatment. High-resolution transmission electron microscopy (HRTEM) can provide direct confirmation of the change in the morphology at the near-surface regions of the materials after the electrochemical process, as shown in Fig. 4(a) and 4(b). Noticeably, after the reaction, the surface of LCF experienced a slight change. While, a visible amorphous surface layer with a thickness of about $3 \mathrm{~nm}$ could be observed in LSCF64, as plotted in Figs. S6(a) and S6(b). Furthermore, the amorphous surface layer of LSCF28 reached a thickness of about $6 \mathrm{~nm}$ in Fig. 4(c) and 4(d). It was previously mentioned that the amorphous layer is the actual origin of the OER activity. Here, from the XAS study, we found that the valence states of Co and Fe ions have almost no effect on the formation of the amorphous layer. Although the $02 p$ holes appear upon Sr doping, it cannot fully compensate the $\mathrm{Sr}$ doping level. Therefore we can safely conclude that the surface amorphous layer, which is the true origin of the OER activity, is related to the occurrence of the oxygen vacancies upon heavily increasing the $\mathrm{Sr}$ doping level.

In conclusion, we reported a system of Sr-doped perovskite prepared by the molten salt method. The LSCF28 component $(\mathrm{Sr}=0.8)$ in the system exhibited the best OER activity with a low overpotential of $0.35 \mathrm{~V}$ and small Tafel slope of $87 \mathrm{mV}$ $\mathrm{dec}^{-1}$ in $0.1 \mathrm{~mol} \mathrm{~L}^{-1} \mathrm{KOH}$. More importantly, we found that: (1) Sr-doping leads to the formation of an amorphous layer, whose thickness increases with the Sr content; (2) upon Sr-doping, the valence states of the Co and Fe ions remain nearly unchanged, whereas $02 p$ holes appear, which cannot compensate the $\mathrm{Sr}$ doping level. From the above observation, we can conclude that the Sr doping results in oxygen vacancies and the formation of
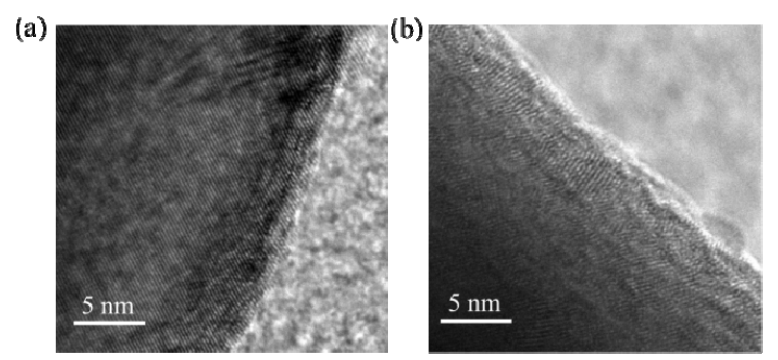

(c)

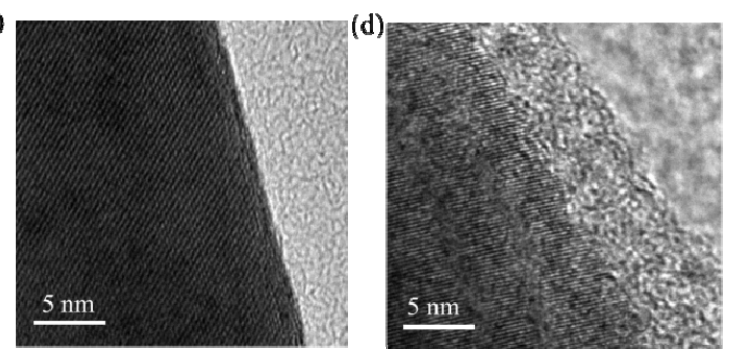

Fig. 4. HRTEM of LCF (a) before and (b) after the OER process; HRTEM of LSCF28 (c) before and (d) after the OER process.

an amorphous layer, which is responsible for the outstanding OER activity. Our finding provides new insights into the design of active OER catalysts.

\section{Acknowledgments}

We thank Renduo Liu and Yu Wang for help with TEM and XAFS measurements, respectively.

\section{References}

[1] S. Chu, A. Majumdar, Nature, 2012, 488, 294-303.

[2] B. M. Hunter, H. B. Gray, A. M. Muller, Chem. Rev., 2016, 116, 14120-14136.

[3] Y. Yan, B. Y. Xia, B. Zhao, X. Wang, J. Mater. Chem. A, 2016, 4, 17587-17603.

[4] J. Wang, W. Cui, Q. Liu, Z. Xing, A. M. Asiri, X. Sun, Adv. Mater., 2016, 28, 215-230.

[5] C. Yuan, H. B. Wu, Y. Xie, X. W. Lou, Angew. Chem. Int. Ed., 2014, 53, 1488-1504.

[6] Q. Zhao, Z. Yan, C. Chen, J. Chen, Chem. Rev., 2017, 117, 10121-10211.

[7] H. Jiang, Q. He, Y. Zhang, L. Song, Acc. Chem. Res., 2018, 51, 2968-2977.

[8] H. Jiang, Q. He, X. Li, X. Su, Y. Zhang, S. Chen, S. Zhang, G. Zhang, J. Jiang, Y. Luo, P. M. Ajayan, L. Song, Adv. Mater., 2019, 31, 1805127.

[9] M. Risch, A. Grimaud, K. J. May, K. A. Stoerzinger, T. J. Chen, A. N. Mansour, Y. Shao-Horn, J. Phys. Chem. C, 2013, 117, 8628-8635.

[10] K. J. May, C. E. Carlton, K. A. Stoerzinger, M. Risch, J. Suntivich, Y.-L. Lee, A. Grimaud, Y. Shao-Horn, J. Phys. Chem. Lett., 2012, 3, 3264-3270.

[11] W. Xu, H. Wang, Chin. J. Catal., 2017, 38, 991-1005.

[12] E. Fabbri, M. Nachtegaal, T. Binninger, X. Cheng, B. J. Kim, J. Durst, F. Bozza, T. Graule, R. Schaublin, L. Wiles, M. Pertoso, N. Danilovic, K. E. Ayers, T. J. Schmidt, Nat. Mater., 2017, 16, 925-931.

[13] S. Song, J. Zhou, X. Su, Y. Wang, J. Li, L. Zhang, G. Xiao, C. Guan, R. Liu, S. Chen, H.-J. Lin, S. Zhang, J.-Q. Wang, Energy Environ. Sci., 2018, 11, 2945-2953. 


\title{
Graphical Abstract
}

Chin. J. Catal., 2020, 41: 592-597 doi: S1872-2067(19)63441-8

Understanding the origin of high oxygen evolution reaction activity in the high $\mathrm{Sr}$-doped perovskite

Sanzhao Song, Jing Zhou, Jian Sun, Shiyu Zhang, Xiao Lin, Zhiwei $\mathrm{Hu}$, Jun Hu, Linjuan Zhang *, Jian-Qiang Wang Shanghai Institute of Applied Physics, Chinese Academy of Sciences, China; University of Chinese Academy of Sciences, China; Dalian National Laboratory for Clean Energy, Chinese Academy of Sciences, China; Max Planck Institute for Chemical Physics of Solids, Germany

Sr-doping leads to oxygen vacancies and the formation of an amorphous layer, whose thickness increases with the $\mathrm{Sr}$ content. The amorphous layer is responsible for the high oxygen evolution reaction activity.

[14] M. Gorlin, P. Chernev, J. Ferreira de Araujo, T. Reier, S. Dresp, B. Paul, R. Krahnert, H. Dau, P. Strasser, J. Am. Chem. Soc., 2016, 138, 5603-5614.

[15] M. Favaro, J. Yang, S. Nappini, E. Magnano, F. M. Toma, E. J. Crumlin, J. Yano, I. D. Sharp, J. Am. Chem. Soc., 2017, 139, 8960-8970.

[16] J. Liu, Y. Ji, J. Nai, X. Niu, Y. Luo, L. Guo, S. Yang, Energy Environ. Sci,, 2018, 11, 1736-1741.

[17] J. Suntivich, K. J. May, H. A. Gasteiger, J. B. Goodenough, Y. Shao-Horn, Science, 2011, 334, 1383-1385.

[18] A. Vojvodic, J. K. Nørskov, Science, 2011, 334, 1355-1356.

[19] L. C. Seitz, C. F. Dickens, K. Nishio, Y. Hikita, J. Montoya, A. Doyle, C. Kirk, A. Vojvodic, H. Y. Hwang, J. K. Norskov, T. F. Jaramillo, Science, 2016, 353, 1011-1014.

[20] J. Hwang, R. R. Rao, L. Giordano, Y. Katayama, Y. Yu, Y. Shao-Horn, Science, 2017, 358, 751-756.

[21] P. F. Liu, X. Li, S. Yang, M. Y. Zu, P. Liu, B. Zhang, L. R. Zheng, H. Zhao, H. G. Yang, ACS Energy Lett., 2017, 2, 2257-2263.

[22] S. Jin, ACS Energy Lett., 2017, 2, 1937-1938.

[23] W. Weng, L. Tang, W. Xiao, J. Energy Chem., 2019, 28, 128-143.

[24] J. Wang, B. Ding, X. Hao, Y. Xu, Y. Wang, L. Shen, H. Dou, X. Zhang, Carbon, 2016, 102, 255-261.

[25] S. She, J. Yu, W. Tang, Y. Zhu, Y. Chen, J. Sunarso, W. Zhou, Z. Shao, ACS Appl. Mater. Interfaces, 2018, 10, 11715-11721.

[26] S. Song, J. Zhou, S. Zhang, L. Zhang, J. Li, Y. Wang, L. Han, Y. Long, Z. $\mathrm{Hu}$, J.-Q. Wang, Nano Res., 2018, 11, 4796-4805.
[27] M. Risch, F. Ringleb, M. Kohlhoff, P. Bogdanoff, P. Chernev, I. Zaharieva, H. Dau, Energy Environ. Sci, 2015, 8, 661-674.

[28] M. Belli, A. Scafati, A. Bianconi, S. Mobilio, L. Palladino, A. Reale, E. Burattini, Solid State Commun., 1980, 35, 355-361.

[29] J. Wong, F. W. Lytle, R. P. Messmer, D. H. Maylotte, Phys. Rev. B, 1984, 30, 5596-5610.

[30] M. Croft, D. Sills, M. Greenblatt, C. Lee, S. W. Cheong, K. V. Ramanujachary, D. Tran, Phys. Rev. B, 1997, 55, 8726-8732.

[31] M. Sikora, C. Kapusta, K. Knizek, Z. Jirak, C. Autret, M. Borowiec, C. J. Oates, V. Prochazka, D. Rybicki, D. Zajac, Phys. Rev. B, 2006, 73, 094426.

[32] D. Drevon, M. Gorlin, P. Chernev, L. Xi, H. Dau, K. M. Lange, Sci. Rep., 2019, 9, 1532.

[33] H. Zhang, J. Liu, G. Zhao, Y. Gao, T. Tyliszczak, P. A. Glans, J. Guo, D. Ma, X. H. Sun, J. Zhong, ACS Appl. Mater. Interfaces, 2015, 7, 7863-7868.

[34] D. Guan, J. Zhou, Z. Hu, W. Zhou, X. Xu, Y. Zhong, B. Liu, Y. Chen, M. $\mathrm{Xu}$, H. J. Lin, C. T. Chen, J. Q. Wang, Z. Shao, Adv. Funct. Mater., 2019, 29, 1900704.

[35] T. Mizokawa, Y. Wakisaka, T. Sudayama, C. Iwai, K. Miyoshi, J. Takeuchi, H. Wadati, D. G. Hawthorn, T. Z. Regier, G. A. Sawatzky, Phys. Rev. Lett., 2013, 111, 056404.

[36] Y. Gorlin, T. F. Jaramillo, J. Am. Chem. Soc., 2010, 132, 13612-13614.

[37] L. Peng, S. S. A. Shah, Z. Wei, Chin. J. Catal., 2018, 39, 1575-1593.

\section{$\mathrm{Sr}$ 掺杂钙钛矿体系中高活性氧析出反应机制}

\author{
宋三召 ${ }^{\mathrm{a}}$, 周 靖 ${ }^{\mathrm{a}, \mathrm{c}}$, 孙健 ${ }^{\mathrm{a}, \mathrm{b}}$, 张诗雨 ${ }^{\mathrm{a}, \mathrm{b}}$, 林 逍 ${ }^{\mathrm{a}, \mathrm{c}}$, Zhiwei Hu $\mathrm{H}^{\mathrm{d}}$, 胡 钧 ${ }^{\mathrm{a}, \mathrm{b}}$, 张林娟, b,c, ${ }^{\mathrm{*}}$, 王建强 ${ }^{\mathrm{a}, \mathrm{b}, \mathrm{c}}$ \\ a 中国科学院上海应用物理研究所, 中国科学院微观界面物理与探测重点实验室, 上海201800, 中国 \\ $\mathrm{b}$ 中国科学院大学, 北京 100049 , 中国 \\ $\mathrm{c}$ 中国科学院洁净能源创新院, 辽宁大连 116023 , 中国 \\ 德国马普固体化学物理研究所, 德累斯顿01187, 德国
}

摘要: 析氧反应(oxygen evolution reaction, OER)是电催化分解水、二氧化碳还原、金属-空气电池以及燃料电池等能源转化 及存储技术的关键过程, 因此被广泛关注和研究. OER过程涉及四个电子转移, 是动力学迟滞过程, 具有较大的过电位, 此 外OER催化反应的同时也可能改变电极表面状态, 故其机理的研究十分困难. 设计和开发高效OER催化剂材料是提高电 解水效率的关键. 最近的研究发现反应后催化剂表面会发生重构, 进而形成无定形层, 该无定形层被认为会改善催化活性. 我们的前期研究也发现了表面不饱和配位无定形层的存在, 但对于重构机制尚没有明确的解释. 本文在上述研究基础上, 
利用熔盐法合成了一系列具有多孔结构的不同 $\mathrm{Sr}$ 含量的 $\mathrm{LaCo}_{0.8} \mathrm{Fe}_{0.2} \mathrm{O}_{3-8}$ 钻钛矿材料, 通过电化学装置测试其催化活性, 并 采用X射线衍射(XRD)、扫描电子显微镜(SEM)、高分辨透射电镜(HRTEM)、比表面积测试(BET)和软硬X射线吸收谱技术 等表征手段对其进行了深入探索.

$\mathrm{XRD}$ 测试结果表明, $\mathrm{Sr}$ 掺杂 $\mathrm{LaCo}_{0.8} \mathrm{Fe}_{0.2} \mathrm{O}_{3-8}$ 钻铁矿材料的主峰随着 $\mathrm{Sr}$ 含量增加向低角度偏移, 这是由于 $\mathrm{Sr}$ 的离子半径较 La的大. SEM和BET测试结果表明, 不同 Sr含量样品均表现出多孔的钙针矿结构, 并具有相似的比表面积, 说明 $\mathrm{Sr}$ 含量变化 不影响催化剂的形貌和比表面积. 利用硬X射线吸收谱对体相 Co和 Fe元素的价态进行了研究, 发现随着 Sr含量的增加, Co 和 $\mathrm{Fe}$ 离子的价态没有明显变化. 类似地, 利用软 X射线吸收谱对表面层 $\mathrm{Co}$ 和 $\mathrm{Fe}$ 价态进行的研究发现, $\mathrm{Co}$ 和 $\mathrm{Fe}$ 均表现出 +3 价, 但在氧元素的 K边吸收谱上观察到明显的氧空穴存在. 电化学测试结果表明, 催化剂的活性随 $\mathrm{Sr}$ 含量增加而增大. 总之, 随 着 $\mathrm{Sr}$ 的掺杂, 催化剂形貌及活性元素价态均无明显变化, 但样品的电化学性能却发生了明显改善, 这意味着尚有其它因素 影响催化剂活性. 利用HRTEM对OER反应前后的样品进行了形貌分析, 发现在OER反应后Sr掺杂的催化剂表面出现了明 显的无定形层, 而无 $\mathrm{Sr}$ 掺杂的样品反应前后几乎未观察到表面形貌的变化. 由此我们推断, Sr掺杂可诱导催化剂表面出现 无定形层, 进而提高OER反应活性. 因此, 在 $\mathrm{LaCo}_{0.8} \mathrm{Fe}_{0.2} \mathrm{O}_{3-8}$ 钙铁矿材料体系中, $\mathrm{Sr}$ 掺杂是影响OER催化剂表面重构和制约 催化活性的关键.

关键词: 熔盐法; 钙钑矿; 氧析出反应; 表面重构; 氧空穴

收稿日期: 2019-10-07. 接受日期: 2019-11-03. 出版日期: 2020-04-05.

*通讯联系人. 电话: (021)39194148; 传真: (021)39194028; 电子信箱: zhanglinjuan@sinap.ac.cn

基金来源：中国科学院战略性先导科技专项变革性洁净能源关键技术与示范(XDA21000000); 中国科学院青年创新促进会 (2014237); 国家自然科学基金 (21876183); 中国科学院科研仪器设备研制项目(YJKYYQ20180066).

本文的电子版全文由Elsevier出版社在ScienceDirect上出版(http://www.sciencedirect.com/science/journal/18722067). 